\title{
Rus Ortodoksluğunu Protesto Etmenin İmkânı: Malakanlar/Manevi Hıristiyanlar
}

Şir Muhammed DUALI*

The Possibility of Protesting the Russian Orthodox: Malakans the Spritual Christians

Citation/@: Dualı, Şir Muhammed, (2018). The Possibility of Protesting the Russian Orthodox: Malakans the Spritual Christians, Milel ve Nihal, 15 (1), 78-98.

Abstract: It has been seen that there are dozens of movements that regarded as heretical in almost every period of Christian history. Especially, more than one religious movement appeared under the name of Protestantism against Catholicism in the West since $15^{\text {th }}$ century. This case reflected in Orthodox world and particularly several separatist groups became apparent in Tsardom Of Russia. So, in this article deals with the Malakanism movement, whose roots date back to the fifteenth century as a protest against Orthodoxy. In this respect, firstly the origin, development, belief and worship of Malakan faith will be explored. After that, it's focused on the similar and different aspects of Malakanism and Protestantism. Besides, it's questioned the failure reasons of Malakan movement to achieve success as Protestantism.

Key Words: Malakans, Orthodox, Protestant, Tsardom Of Russia, Heretic, Mystical.

* $\quad$ Dr. Öğr. Üyesi, Gaziosmanpaşa Üniversitesi İlahiyat Fakültesi Dinler Tarihi Anabilim Dalı [ muhammed.duali@gop.edu.tr]. 
Rus Ortodoksluğunu Protesto Etmenin İmkânı: Malakanlar/Manevi Hıristiyanlar

Atıf/C): Dualı, Şir Muhammed, (2018). Rus Ortodoksluğunu Protesto Etmenin İmkânı: Malakanlar/Manevi Hıristiyanlar, Milel ve Nihal, 15 (1), 78-98.

Öz: Hıristiyanlık tarihi incelendiğinde hemen her dönemde heretik addedilen onlarca akımın ortaya çıkmıştır. Özellikle on beşinci yüzyıldan itibaren Katolisizm'e karşı Batıda birden fazla dini oluşumun Protestanlık şemsiyesi altında gün yüzüne çıkmıştır. Bu husus, Ortodoks Hıristiyan dünyasında da yankı bulmuş ve özellikle Çarlık Rusyası'nda kimi ayrılıkçı hareketler belirmiştir. Bu çalışma, Ortodoksluğa bir protesto mahiyetinde teşekkül eden Malakanizm hareketini konu edinmektedir. Bu çerçevede ilk olarak Malakan inancının ortaya çıkışı, gelişimi, inanç ve ibadet esasları araştırma konusu edinilmekte, Malakanizm ile Protestanlık arasında benzer ve ayrışan noktalar üzerinde durulmaktadır. Ayrıca Malakanizm hareketinin Protestanlık kadar başarı elde edemeyişinin nedenleri tespit edilmeye çalışılmaktadır.

Anahtar Kelimeler: Malakan, Ortodoks, Protestan, Çarlık Rusya'sı, Heretik, Mistik.

\section{Giriş}

Rusya, özellikle XVI. yüzyıldan itibaren çoğunluğu Ortodokslardan oluşan ancak farklı dini ve etnik kimlikleri de bünyesinde barınd1ran bir devlet konumundadır. Özellikle XVIII. yüzyıl boyunca hem iç hem de diş faktörler nedeniyle Ortodoks Kilisesi içerisinde birden fazla dini fraksiyonun ortaya çıktığ görülmektedir. Bu faktörlerden ilki, Çarlık Rusya'sında hüküm süren köylü sorunu ve toplum arasinda var olan adaletsizlikler iken, ikincisi de başta Protestanlık ${ }^{1}$ olmak üzere Batıda ortaya çıkan yeni dini oluşumların Ortodoks toplum üzerindeki etkileridir. Batıdaki örneklerden etkilenilerek geliştirilen dini oluşumlar, halkın maruz kaldığı adaletsizliklerin ortadan kaldırılması ve adil bir düzenin tesis edilmesi adına mevcut statükoya başkaldırı özelliği taşımaktadır. Bir köylü ayaklanmasına dönüşen bu başkaldırıların en önemlisi 1773-1775 yılları arasında meydana gelen Pugachev isyanıdır. ${ }^{2}$ Bu gelişmeler, bir köylü ayaklanması olduğu kadar dinde reformlar şeklinde de tezahür etmiştir. Aslında Rus Ortodoksluğu içerisinde ortaya çıkan heretik akımların tarihini, Rusların 988'de Hıristiyanlığın Ortodoks mezhebini resmi din olarak kabul ettiği dönemlere kadar götürmek mümkündür.

131 Ekim 1517 Tarihinde Martin Luther' in Papalık otoritesine karşı yayınlanan 95 maddelik tezi sonrası şekillenen Protestanlık, başta Papaların öncülük ettikleri Konsil kararları olmak üzere kilise dogmaları, Endüljanslar ve günah bağışlama gibi konularda Katolik Kilise doğmalarına karşı çıkmıştır. Hakan Olgun, Luther ve Reformu Katolisizm'i Protesto, Eskiyeni Yayınları, 2. Baskı, Ankara, 2016, s. 49.

2 Muratov I, Krestyanskaya Voyna Pod Predvoditelstvom Y. İ. Pugacheva (1773-1775), Prosveshcheniye Moskova, 1980, s. 51. 
Şöyle ki Rus kilise tarihi incelendiğinde resmi Ortodoks hiyerarşisine ilk olarak 1004'lü yıllarda Adrian adında bir keşişin karşı çıtığını görürüz. Adrian ve ortaya koyduğu görüşleri, Ortodoks baskısı ve takibi sonucu ortadan kalkmıştır. Ortodoksluğa karşı yeni başkaldırılara Moğol Tatar istilasının sürdüğü 1300'lü yıllarda da rasgelmekteyiz. İsmini hareketin kurucusu Carpa Strigolnik'ten (стригольники) alan hareket, kilise hiyerarşisini reddederek yönetimin topluma ait olduğunu ileri sürmüş, kilise ayinlerini kaldırmış ve evliliklerin rahip kutsaması olmaksızın gerçekleşebileceğini iddia etmiştir. ${ }^{3}$ Ortodoks kilisesi tarafından heretik sayılan Strigolnikler, uzun yıllar boyunca takibata uğramış ve nihayetinde 1376 yılında önemli ölçüde etkinliğini yitirmiştir ${ }^{4}$

$X V$. yüzyılın sonlarına gelindiğinde de yine benzer düşünce ve davranışları sergileyen ve "Jidovstva" 5 olarak da tanımlanan yeni bir heretik akım ortaya çımıştır. 1471 yılında şekillenen hareketin kurucusu Litvanya asıllı bir Yahudi olan Zaharia'dır. O ileri sürdüğü düşünceleri ile sadece sıradan halkı değil aynı zamanda birden fazla ruhbanı da etkilemeyi başarmıştır. Durumu kontrol altına almayı hedefleyen Rus Ortodoks Kilisesi 1490 yılında bir konsey toplamış ve Jidovstva hareketini aforoz ederek yok edilmesine karar vermiştir. Bu süreçte iktidarda olan Rus Çarı III. İvan'ın (ö. 1505) Ortodoks Kilisesi ile bir anlaşmaya vardığını da belirtmekte yarar olacaktır. Zira Çar, kendisinin kilisede mutlak otorite olarak kabul edilmesi karşılığında Jidovstva hareketi ile mücadelede kilisenin yanında yer alacağını beyan etmiştir. Rus Kilisesinin bu şartı kabul etmesinden sonra Jidovstva hareketine karşı amansız bir mücadele başlamış ve kısa bir zaman diliminde hareketin etkisi kırılmıştır. Bu tarihten itibaren Kilise, otokrasinin temel dayanağı haline gelirken, Moskova da Rus devletinin dünyevi ve dini merkezine dönüşmüş, bir bakıma Bizans'ta mevcut olan "Sezaropapizm" benzeri bir yapılanma Rus yönetiminde de vücut bulmaya yüz tutmuştur. Önemli ölçüde yeraltına çekilen Jidovstva hareketi, bu sefer XVI. yüzyılın sonlarında Moskova'da yeniden gün yüzüne çıkmış ve zamanla iki farklı kola ayrılmıştır. Bunlardan ilki, akılcılığı temel dayanak edinmekle birlikte Yahudi inancından önemli ölçüde yararlanırken bir

3 Semenov İ. Y., İstoriya Zakavkazskikh Molokan i Dukhoborov, Avtorskoye İzdaniye, Yerevan, 2001, s. 9.

4 Andrey K. Doobovoy, History of the Russian Protestant Religious Movement, Journal the Sun, Sayı, 7-9, 1938, s. 19.

5 Şir Muhammed Dualı, Çarlık Rusya'sında Yahudiler, Divan Kitap, Ankara, 2016, s. 50 . 
diğeri de Bashkin ile Kosoy isimli rahiplerce oluşturulan ve Yahudi inancından arındırılmış bir yapıyı temsil eden harekettir. Bu hareketlerden ilki zamanla Subbotniki (субботники) уani Şabatçılar olarak ortaya çıkacak olan heretik bir akımın da öncüsü konumundaydı. Bashkin ile Kosoy'un ortaya koydukları düşünce ise daha sonra ortaya çıkacak olan Malakanizm hareketinin öncüsü mesabesindedir. Zira Bashkin ile Kosoy'un öğretisi, kiliseyi ve kilise hiyerarşisini ve Ekümenik konsillerin otoritesini tanımamaktaydı. Kilise ayinleri yerine toplanma mekânlarında sadece İnciller' de yer alan bilgilerin okunmasını ön görmekte, ikonaları da reddetmekteydi. ${ }^{6}$ Ortodoks Kilisesi'ne karşı bir başkaldırı olarak ortaya çıkan Bashkin ve Kosoy'un oluşturduğu hareket, tüm baskı ve takiplere rağmen iki yüz yıl boyunca etkisini sürdürmeyi başarmıştır. Kuşkusuz bu süreçte hareket kendini geliştirmiş ve Batıda ortaya çıkan Protestanlıktan da önemli ölçüde etkilenmiştir. Nitekim 1560 yılından itibaren Moskova'da iki Protestan kilise faaliyet göstermeye başlamış, zamanla bu kiliselerin sayısı artmıştır. ${ }^{7}$ Protestan düşüncesinin Rus topraklarına yayılmasının Malakanizm tarzı dini oluşumların ortaya çıkmasına önemli katkısı olmuştur.

Malakanizm hareketi ile ilgili ülkemizde az sayıda çalışmanın olması, konunun önemini daha da artırmaktadır. Ülkemizde Malakanlar ile ilgili yapılan çalışmalar genellikle onların sosyo-kültürel yapıları üzerine yoğunlaşmıştır. O. Türkoğlu'nun Atatürk Üniversitesi İletişim Fakültesi'nde yaptığı ve "Malakanlar' in toplumsal yapısı: Kars ilinin üç köyünde bir Rus etnik grubunun sosyoekonomik araştırması: 1877-1962" başlıklı doktora çalışması buna örnek olarak gösterilebilir. Bu hususta yapılan bir diğer çalışma ise Ç. C. Suvari imzalı "Malakanlar: Rus köylü hareketlerinden günümüze Malakan inancı" başlığı taşımaktadır. Bu çalışma, Azerbaycan'ının İvanovka köyünde yaşayan Malakanlar'ı konu edinmektedir. B. Akça'nın "Malakanlar'ın Anadolu'daki İzleri” başlıklı makale çalışması da Kars'a sürülen Malakan gruplar üzerine yoğunlaşmaktadır. Son olarak, Elşan Musayev tarafından "Azerbaycan'da Hıristiyanlık ve Çağdaş Hıristiyan Akımlar," başlıklı doktora çalışmasını zikredebiliriz. Bu çalışma içerisinde Azerbaycan'da bulunan Malakan, Dukhobor ve Skop gibi Ortodoksluktan ayrılan heretik akımlardan söz edilmektedir.

\footnotetext{
Semenov, İstoriya Zakavkazskikh Molokan i Dukhoborov, s. 12.

Livanov F. V, Raskolniki i Ostrozhniki, Tom I, İzdaniye 4-oye. İzdatelstvo SanktPeterburg, 1872, s. 158.
} 
Bu çalışmada ise Malakanizm ile ilgili aşağıda belirtilen soruların cevapları aranmaktadır:

- Malakanizm hareketinin ortaya çıkmasında hangi faktörler etkin olmuştur?

- Ortodoksluğa bir protesto mahiyetinde şekillenen Malakanizm'in Luther Protestanlığı ile ne denli bağlantısı vardir?

- Malakanizm'in Protestanlık kadar etkin bir harekete dönüşememesinin nedenleri nelerdir?

- Malakanlar'in kendilerini “Manevi Hiristiyanlar" olarak tanımlamalarının gerekçesi nedir?

- Malakanizm düşüncesinde görülen Yahudiliğe ait izler nasıl izah edilebilir?

\section{Malakanizm'in Tarihsel Seyri}

Modern literatürde, Rusya'da ortaya çıkan dini oluşumlar üç temel grup halinde sınıflandırılmaktadır. Bunlardan ilki Ortodoksluk içerisinden neşet eden aykırı hareketlerdir. Bunlara Malakanlar, Dukhoborlar ve Skoplar' $1^{8}$ dâhil etmek mümkündür. Yine bu dini oluşumlar, kendi içlerinde farklı küçük gruplara ayrılmış durumdadırlar. İkinci grup dini oluşumlar ise Protestan-Evanjelik kökenlere dayanan Baptistler ve Evanjelik Hıristiyanlar adı altında ortaya ç1kan dini hareketlerdir. Üçüncü sırada ise Yahudi inancını temel alan dini oluşumlar gelmektedir. Bunlara da Subbotnikler (Şabatçllar) ve Jidovstva hareketini örnek göstermek mümkündür. ${ }^{9}$ Biz burada Rus Ortodoks Kilisesi içerisinden neşet eden dini oluşumlardan Malakanizm üzerinde durmaya çalışacağız. Bunun nedeni Rus Ortodoks Kilisesi bünyesinden neşet eden birçok dini akım içerisinde Malakanlar kadar geniş bir kitleye ulaşan ve günümüze değin varlığını korumayı başaran pek az hareketin olmasıdır.

8 Dukhoborlar: XVIII. yüzyılın sonlarında ortaya çıkan ve Ortodoks Kilisesi tarafından heretik kabul edilen bir oluşumdur. Dukhoborlar da Malakanlar gibi ikonları kabul etmez ve kilise ayinlerine katılmazlar. İnsan bedeninin ruh için bir hapishane olduğuna ve ruh ile beden arasında hep mücadelenin devam ettiğine inanırlar. XVIII. yüzyıl içerisinde ortaya çıkan bir diğer heretik akım olan Skoplar'a göre inanan insanın kurtuluşu ancak ateşle vaftizle mümkündür. Bu ise cinsel organın dağlanması ile gerçekleştirilmektedir. Elşan Musayev, "Azerbaycan'da Hıristiyanlık ve Çağdaş Hıristiyan Akımlar," (Basılmamış Doktora Tezi), Marmara Üniversitesi, İstanbul 2005, s. 15.

9 Khramtsova Yuliya Sergeyevna, "Change Of Molokans Role In The Social Life of Tersk Region, Theory and Practice of Social Development", 10 (2013), s. 279. 
Rus Ortodoksluğunu Protesto Etmenin İmkânı: Malakanlar/Manevi Hıristiyanlar

Yuhanna 4:24'te geçen ve "Tanrı ruhtur, ona tapınanlar da ruhta ve gerçekte tapınmalıdırlar" pasajından hareketle Malakanlar, Tanrı'ya ruh ve hakikatle ibadet ettiklerini ileri sürmek suretiyle kendilerini Manevi/Ruhsal Hiristiyanlar olarak tanımlamaktadırlar. ${ }^{10}$ Ancak Rus Ortodoks Kilise literatüründe "Manevi Hıristiyan" yerine Malakan isminin kullanıldığı görülmektedir. Resmi olarak Malakan tanımlaması ilk kez 1765 tarihinde gerçekleştirilen Ortodoks Kilise Konseyi'nde kullanılmıştır. Rusçada “молоко” уаni "süt" kelimesinden türetilen Malakan isminin ortaya çıkışıyla ilgili çeşitli rivayetler söz konusudur. Bir görüşe göre, Molochnaya Nehri (Süt Nehri) boyunca yerleştikleri için bu isimle anıldıkları ileri sürülmüsstür. ${ }^{11}$ Lakin Malakanlar'ın Süt Nehri kıyılarına sürülme tarihi 1805 yılına tekabül ettiğinden, bu görüşün doğruluğu kuşkulu bir hal almaktadır. Malakan ismi ile ilgili ortaya atılan bir diğer görüşe göre ise Ortodoks Mezhebine muhalefet etmek adına perhiz günlerinde yenmesi ve içilmesi yasak olan süt ve et ürünlerini bolca tüketmeleri Malakan ismiyle anılmalarına neden olmuştur. ${ }^{12}$ Görüldüğü üzere bu isim Malakanlar'a kendi müntesiplerince değil, Ortodoks Kilisesi tarafından verilmiş bir isimdir. ${ }^{13}$ XIX. yüzyılın ortalarına gelindiğinde Malakanlar'ın kendilerine Ortodoks Hıristiyanlarca verilen bu ismi benimsedikleri ve kendilerine Kutsal Kitap'tan şu pasajları referans olarak aldıkları görülmektedir: "Yeni doğmuş bebekler gibi, hilesiz sütü andıran Tanrı sözünü özleyin ki, bununla beslenip büyüyerek kurtuluşa erişesiniz". ${ }^{14}$ Dolaysıyla da bu dini hareket, öteden beri hem "Malakanlar" hem de "Manevi H1ristiyanlar" olarak adlandirılmaktalar.

Tarihi kayıtlar Malakanlar'ın XVIII. yüzyılın ortalarından itibaren Rusya'nın Tambov vilayetinde Don Kazakları arasında neşet ettiğini göstermektedir. ${ }^{15}$ Ancak yukarıda da belirtildiği üzere,

10 Buyanov, Evgeny Valerevich, “Veroucheniye i Techeniya Dukhovnykh Khristian Molokan", Religii Rossii, Religiovedeniye, 2014/4, s. 5.

11 Malakhova İrina, Dukhovnyye Khristiane, İzdatelstvo Politicheskoy Literatury, Moskova, 1970, s. 79.

12 Korsakov V, “Molokane İz Zametok Zemskogo Vracha”, Ruskiy Vestnik, say1 2 ve sayı 10, 1886, s. 3.

13 Christel O. Lane, "Socio-Political Accommodation and Religious Decline: The Case of The Molokan Sect in Soviet Society", Comparative Studies in Society and History, Vol. 17, No. 2 (1975), s. 222.

14 1. Petrus, 2/2. 1. Korintliler, 3/2.

15 Susan W. Hardwick, "Religion and Migration: The Molokan Experience", Yearbook of the Association of Pacific Coast Geographers, Vol. 55 (1993), s. 129. 
Malakan inancının kökleri çok daha eskilere dayanmaktadır. Malakanizm'in kurucusu Rusya'nın Tombov vilayetinde bir köylü olan Semen Uklein'dir (ö.1809). Bir terzi olan Uklein ilk başlarda Protestan rasyonalist akımının kurucusu Tveritinov' ${ }^{16}{ }^{16}$ intisap etmiştir. Malakan rasyonalizminin oluşumunu etkileyen de Tveritinov'un Protestan fikirleri olmuştur. Zamanla etrafına yetmişi aşkın takipçi toplayan Uklein, köy ve kasabaları dolaşarak kendi inancını yaymaya çalışmıştır. Kısa süre içinde tutuklanan Uklein, görüşlerinden vazgeçtiğini belirterek serbest kalmayı başarmışsa da çok geçmeden kendi düşüncelerini yeniden anlatmaya başlamıştır. Orduya hizmeti reddetmesi, sosyal eşitlik talebi ve vergi ödememeyi teşvik etmesi, etrafında yüzlerce kişinin toplanmasını kolaylaştırmıştır. ${ }^{17}$ Malakanlar zamanla Tambov'un dışına taşmış, Malakanist fikirler Çarlığın hemen her tarafında bilinir olmuştur. 1805 yılından itibaren ise Çarlık rejimi sapkın olarak tanımladığı Malakan ve Duhoborlar'ı, şimdiki Kırım yarımadasını da kapsayan Tavricheskaya Vilayetinde bulunan Molochnaya Nehri etrafına sürmek suretiyle Ortodoks toplumdan tecrit etme yoluna gitmiştir. I. Nikolay'ın (ö. 1855) tahta çıkması, Malakanlar açısından zorlu günlerin de başlangıcı olmuştur. 20 Ekim 1830 tarihli Devlet Konseyi tarafından alınan karar uyarınca, Malakanlar resmen sapkın dinî öğreti kapsamına alınmıştır. Bu tarihten itibaren Malakanlar, İmparatorluğun ücra köşelerine zorunlu göçe tâbi tutulmuşlardır. Bu coğrafyaların başında Kafkasya gelmektedir. Halk arasında "sıcak Sibirya" olarak da bilinen Kafkasya coğrafyası, Ortodoks akidesine aykırı hemen her oluşumun sürgün edildiği bir bölge konumuna dönüşmüştür. Dolayısıyla binlerce Malakan ve Dukhobor Azerbaycan, Ermenistan ve Gürcistan sınırları içerisinde ikamete zorlanmışlardır. Heretik bir hareket olarak görülmesine rağmen Malakanlar'ın sürüldükleri coğrafyalarda Ortodoks tebaayı kışkırtmaksızın kendi inançlarına göre ibadet etmelerine göz yumulmuştur. Ayrıca yeniden Ortodoksluğu tercih edenlere yönelik baskı ve takibatın kaldırılacağı garantisi de verilmiştir. 1839 yılı itibarıyla Malakan çocukların eğitim kurumlarına girme haklarının ellerinden alınmış, bir Malakan çocuğun herhangi bir eğitim kurumunda okumaya hak kazanabilmesi,

16 Vaiz olan Tveritinov, Kilise hiyerarşisini ve kutsal Kitap'ın yorumlanmasında kilise otoritesini reddetmekte, ibadetlerin sadeleştirilmesini savunmaktaydı. Morozov İ. P, Molokane, Moskva: OGIZ, Moskovskiy Rabochiy, 1931, s. 3.

17 Morozov, Molokane, s. 11. 
Rus Ortodoksluğunu Protesto Etmenin İmkânı: Malakanlar/Manevi Hıristiyanlar Ortodoks inancını kabul etmesi şartına bağlanmıştır. ${ }^{18} \mathrm{Bu}$ ise Malakanlar'ın sistematik bir biçimde dışlanmalarına ve kendi içlerine kapanmalarına sebep olmuştur.

Malakanlar'ın sistematik bir biçimde baskı ve takibe maruz kalmaları zamanla Tanrı Krallığı'nın yaklaşmakta olduğu inancını ön plana çıkmasına yol açmıştır. Takipçilerini bir arada tutmak ve baskılara göğüs germelerini sağlamak maksadıyla Uklein, 1835 yılını Tanrı Krallı̆̆ı'nın tesis edileceği yıl olarak ilan etmiştir. Krallığın merkezi, yani yeni Kudüs ise Ağrı Dağı civarında kurulacaktır. Uklein' in bazı öğrencileri beklenen günü karşılamak için tüm Malakanlar'ın Ağrı Dağı yakınlarına göç etmeleri gerektiğini ileri sürmüştür. Uklein'in bu kehaneti, bazı radikal Malakanlar'ın gönüllü bir biçimde bulundukları topraklardan göç etmelerinin de önünü açmıştır. Böylelikle 1800'lü yılların sonlarına kadar binlerce Malakan, isteyerek ya da zorla İmparatorluğun çeşitli bölgelerine göçe zorlanmıştır. Bu çerçevede Çarlık sınırları içerisinde bulunan Erivan eyaletine 4.150 civarında Malakan göç ettirilmiştir. Bu sayı Azerbaycan sınırları içerisinde 11.500 kişiye ulaşmışken, Tiflis eyaletinde 3.204 civarında olmuştur. ${ }^{19}$ Gittikleri topraklarda Malakanlar, kendilerini yerli halktan ve diğer dini gruplardan tecrit ederek, bir bütün olarak yaşamaya özen göstermişlerdir. Bu onların ritüelleri ve kabul ettikleri hayat normlarını yerine getirmelerini kolaylaştırmaktaydı. Malakanlar oluşturdukları toplumu, Mesih'in idealize ettiği kardeşlik, sevgi, eşitlik ve özgürlük ilkeleri çerçevesinde tanzim ettiklerini ileri sürmektedirler. Bu nedenle de müreffeh bir hayatın oluşturulması hususunu esas almaktadırlar. Malakanlar'ın eşitlik ve kardeşlik ilkeleri üzerine yaptıkları vurgu o denli ön plana çıkmaktadır ki Çar I. Nikolay (ö. 1855), Malakanlar'1 dini kisve altına saklanmış ve toplumculuğu (sosyalizm) ön gören bir siyasi yapılanma olarak tanımlamıştır. ${ }^{20}$ Çarlık rejimi ve Ortodoks hegemonyasına bir tehdit olarak görülen Malakanlar'a yönelik baskı ve takibin giderek artması zamanla Rusya dışına yönelik Malakan gücünün de önünü açmıştır. Bu çerçevede 1901 ile 1911 yılları arasında 3500 civarında Malakan, uygun bir ortam bulmak amaciyla, Trans Kafkasya'dan

\footnotetext{
İvanovna, "Obshchiny Molokan na Kavkaze”, s. 29-30.

Malakhova, Dukhovnyye Khristiane, s. 80-83.

Yuriy Salin, "Estafeta Garmonii: Ot Palestinskikh Yesseyev do Russkikh, Dalniy Vostok Dukhoborov Rossiyskiy literaturnyy zhurnal", sayı 2, 2006, s. 147. (134158)
} 
Kaliforniya'ya göç etmiş̧tir. ${ }^{21} \mathrm{Bu}$ durum Malakanlar üzerindeki rejim baskısının Çarlığın sonuna değin devam ettiğini ortaya koymaktadır.

Sonuç olarak Kafkasya coğrafyasının 1800'lü yılların başlarından itibaren Rus hâkimiyetine girmesi, daha sonraları ise 93 Harbi (1877-1878) ile birlikte Osmanlı'nın Kars22, Ardahan ve Batum'u Ruslara terk etmesi, İmparatorluk içerisinde istenmeyen dini oluşumların elde edilen yeni bölgelere sürgün edilmelerinin önünü açmıştır. Bu çerçevede 1830-1890 tarihleri arasında Kafkasya coğrafyası Ortodoks bünyeden kopan yeni dini oluşumların sürgün bölgesi haline getirilmiştir. Böylelikle Rus devleti, Ortodoks halkı tehlikeli addedilen akımlardan izole etmek suretiyle, toplum içerisinde meydana gelecek kargaşanın da önüne geçmiş oluyordu.

İmparatorluğun çeşitli coğrafyalarına göç ettirilen Malakanlar zamanla farklı fraksiyonlara ayrılmıştır. Bunlardan bazılarının ömrü kısa iken bazıları da uzun müddet varlıklarını idame ettirmeyi başarmıştır. Örneğin 1836 yılında kendisinin İsa Mesih olduğunu iddia eden Lukyan Petrov adında bir şahsın Malakanlar arasında önemli ölçüde bir ayrışmaya yol açttğı görülmektedir. Mesih olduğuna halkı inandırmak için daha önceden anlaştı̆̆ bazı şahısları ölmüş gibi davranmaya ikna etmiş ve daha sonra onları diriltmek suretiyle mucize gösterdiğini iddia etmiştir. Kendine inananlara Tanrı'nın Krallığı için güzel elbiselerini giyerek Ağrı Dağı civarına göç etmelerini telkin etmiştir. İbadet esnasında takipçilerini vecde

21 Ethel Dunn and Stephen P. Dunn, "The Molokans in America", Dialectical Anthropology, Vol. 3, No. 4 (1978), s. 49.

22 On dokuzuncu yüzyılın sonunda Kars bölgesinin toplam nüfusu 207374 kişi olmuştur. Bölgedeki Hıristiyan nüfus ise yaklaşık 15 bin civarındadır (\%15). Söz konusu tarihlerde bölgede Malakan ve Dukhoborın oluşturduğu 18 Rus köyü varlık göstermiştir. Bunlar sırasıyla Vorontsovka (8675 kişi), Novo-Mikhaylovka (1000 kişi), Blagodarnoye (1000 kişi), Prokhladnoye (473 kişi), Yeni-Dubovka Malo (523 kişi), Romanovka (832 kişi), Novo-Aleksandrovka ve Nova-Selim (1221 kişi) ve Elenovka 719 kişi) yaşamaktaydı. 25 Nisan 1918' de Kars'ın, tekrar Osmanlı topraklarına dâhil edilmesi sonrası, burada yaşayan Malakan ve Dukhoborların Rus topraklarına dönmelerine izin verilmiştir. Geri dönüşler 1961 yılında tamamlanmıştır. Ancak ateizmin resmi ideoloji olduğu Sovyetlerde ciddi sorunlarla karşılaşan Malakanlardan 50 kişi Türkiye'ye geri dönme isteklerini belirten dilekçelerini 1966 yılında Türkiye'nin Moskova Konsolosluğuna iletmek istemişse de buna müsaade edilmemiştir. Karskaya Oblast, Entsiklopedicheskiy Slovar Brokgauza i Efrona, Petersburg, 1899. T. XXVI (51) s. 290. 
Rus Ortodoksluğunu Protesto Etmenin İmkânı: Malakanlar/Manevi Hıristiyanlar getirmek için birtakım dualar ve ilahiler eşliğinde sıçramayı ve zıplamayı önerdiğinden, hareketin adı zamanla "sıçrayanlar" (прыгуны) olarak anılmıştır. Petrov, bu davranışını Kral Davud'un Rabbin önünde sıçrayarak oynamasına bağlamıştır. ${ }^{23}$ Günümüzde de varlıklarını sürdüren Sıçrayanlar, kendilerini Malakanlar içerisinden seçilenler olarak addetmekte ve bin yıllık Mesih Krallığı geldiğinde bu krallıkta ayrıcalıklı bir konumda olacaklarına inanmaktadirlar.

\section{Malakan Tanrı Anlayışı}

Ortodoksluğa dolaysıyla da Hıristiyanlığın ortaya koyduğu din anlayışına bir protesto özelliği taşıyan Malakanizm, Tanrı ve onun mahiyeti konusunda da kendine özgü bir bakış açısı geliştirmiştir. Protestanlıktan farklı olarak tüm Kilise konsillerini reddeden Malakanlar, İznik Konsili'nde temelleri atılan Tanrı'nın üçlüğü hususunu uknum/hipostas kabul etmezler. Malakan inancına göre Tanrı, tek ve bölünmez bir bütündür. Kendini Baba, Oğul ve Kutsal Ruh olarak nitelendirmiş ve tekliğinde ezelden ebede bu üç benlik çerçevesinde var olmuştur. Görüldüğü üzere Malakanlar teslis inancını reddetmekteler ve Tanrı'nın tekliğine vurgu yapmaktadırlar. Dolayısıyla Malakanlar Tanrı ve onun hakikati hususunda şöyle derler: “Tek Tanrı'ya Baba'ya inanırız ve kutsal isimlerine tapınırız. O birliği, özü, hakikati, özgürlüğü, güzelliği temsil eder. Tanrı sayısız imgelerde tezahür eder ve isimlerinin de sonu yoktur. O her şeye kadirdir her şeye gücü yetendir ve her yerde hazır ve nazırdır. ${ }^{24}$ Eski Ahit'in on emrine gönderme yapan Malakanlar, ikonaların birer put $^{25}$ mesabesinde olduğunu ve puta tazimin günah ve Tanrı'ya ortak koşmakla eşdeğer olduğuna inanmaktadırlar. Malakanlar Tanrı'nın şu üç yolla bilinebileceğine inanmaktadırlar. Bunlardan ilki kişinin iç/ruhani dünyasıyla ilgilidir. Zira kişi onu bilme hususunda içten ve samimi davranır ise Tanrı o kişinin ruhuna kendini açacaktır. Bir diğer ise dış dünyanın idrak edilmesi ile mümkündür. Zira Malakanlar, doğada mevcut güzelliklerin ve düzenin idrak edilmesi suretiyle Tanrı'nın bilinebileceğini belirtmektedirler. Ancak Tanrı'nın bilinmesi hususunda en etkin yöntem, Kutsal Kitap'ın önderliğini kabul etmektir. ${ }^{26}$ Bu hususa ise Galatyalılar 1:8' de yer

\footnotetext{
23 "Keten efod kuşanmış Davut, Rabbin önünde sıçrayarak oynuyordu". 2. Samuel 6/14.

24 Morozov, Molokane, s. 13-14.

25 Misır'dan Çıkış 20/3-4.

26 Morozov, Molokane, s. 17.
} 
alan "İster biz, ister gökten bir melek size bildirdiğimize ters düşen bir müjde bildirirse, lanet olsun ona!" ifadesini delil göstermekteler.

\section{a) Mesih Anlayışı}

Malakanlar açısından Yüksek kâhin olarak kabul edilen İsa Mesih, İnsanlığın kurtuluşu için Bakire Meryem'den babasız dünyaya gelmiştir. ${ }^{27}$ Ancak Meryem'den doğan Mesih'in bedeni (Lat, caro) insani bir beden değildir. Onun bedeni, Tobit Kitabında ${ }^{28}$ bahsi geçen Baş Melek Rafael'in bedeni gibidir. Mamafih Mesih'in bedeni de cennetten getirilmiş ve Meryem'in rahmine yerleştirilmiştir. Mesih yeryüzüne insanları günahtan kurtarmak ve yeniden İbrahim'in yoluna yöneltmek için gelmiş bulunmaktadır. Malakan inancına göre bir insan bedenine sahip olmayan İsa Mesih'in ölümü de sıradan insanların ölümü gibi olmamıştır. ${ }^{29}$ Onlara göre kilisenin hakiki piskoposu ve yüksek kâhini sadece İsa Mesih'tir ${ }^{30}$ ve her hangi bir beşer bu makama layık olamaz. Dolayısıyla Tanrı dişında her hangi bir şahıs veya varlık önünde eğilmeyi Kutsal Kitaba aykırı bulan Malakanlar, özellikle askerlik ve yemin ile ilgili yasaları da Tanrı'dan başkasına itaati gerektirdiğinden kabul etmemişlerdir. Malakanizm her ne kadar birçok açıdan Protestanlığı anımsatıyor olsa da özellikle kişinin kurtuluşu konusunda ondan ayrılmaktadır. Protestanlığa göre kişinin kurtuluşu sadece Tanrı'nın inayetine, bir anlamda ona iman etmiş olmaya bağlıdır ve kişinin dindarlığının, yaptığı iyi amellerle bir bağlantısı yoktur. Özetle Protestanlık'ta kurtuluş, Tanrı'nın rahmeti, Mesih'in fazileti ve iman sayesinde mümkün olmaktadır. ${ }^{31}$ Ancak Malakan inancına göre bir kişinin kurtuluşu, o kişinin ahlaki, vicdani ve insani çabaları ile doğrudan ilintilidir. ${ }^{32}$ Nitekim insanın Tanrı ile irtibatı yaratılışından hayatının sonuna kadar kendine özgü bir zorunluluk halinde devam eder. Bu nedenle

\footnotetext{
Matta 1/20.

Mesih öncesi dönemde Yahudi dinini ve kültürünü ele alan bu kitap, inançlı kişilerin karşılaştıkları olağanüstülükleri konu edinmektedir.

29 Bulgakov Sergey Vasilyevich, Spravochnik po Yeresyam, Sektam $i$ Raskolam, DirektMedia, Moskova, 2014, s. 97.

30 Tanrı Oğlu İsa gökleri aşan büyük Baş kâhinimiz olduğu için açıça benimsediğimiz inanca sımsıkı sarılalım. İbraniler 4/14

31 Hakan Olgun, Luther ve Reformu, s. 116.

32 Buyanov, Evgeny Valerevich, "Veroucheniye i Techeniya Dukhovnykh Khristian Molokan", Religiovedeniye, 2014/4, s. 4
} 
kişinin bu dünyada yapması gereken Tanrı'ya olan sevgisini pekiştirmek ve kendini öteki dünyaya hazırlamak olmalıdır. Malakanlar'a göre bunun gerçekleşmesi ancak kilisenin ortaya koyduğu ritüel ve hiyerarşi gibi engellerin ortadan kaldırılmasıyla mümkün olacaktır. ${ }^{33}$ Görüldüğü üzere Malakanlar'ın Mesih anlayışı, Protestanlığın Mesih anlayışından ayrılmaktadır. Protestanlıkta Mesih kişinin kurtuluşunda kilit bir rol oynarken, Malakanizmde kurtuluş İman ve iyi amellere bağlıdır.

\section{Malakan İnanç ve Ritüelleri}

Rus Ortodoksluğu içerisinde ortaya çıkan Malakanizm ve benzeri dini eğilimlerin önemli özelliklerinden biri de Tanrı ile doğrudan iletişim kurma ihtimaline olan inançtır. Dolayısıyla bu öğretinin takipçileri, Eski Ahit ayinlerini ve diğer Hristiyan kiliselerince ortaya konulan ritüelleri reddetmişlerdir. Malakanlar'a göre bütün dinsel formaliteden uzak olmaları, onların Tanrı'ya yönelik ruh ${ }^{34}$ ve hakikatle ibadet etmelerine fırsat sunmaktadır. ${ }^{35} \mathrm{Bu}$ çerçevede kilise hiyerarşisini ve geleneği reddeden Malakanlar, kendi inançları bağlamında uyguladıkları neredeyse bütün davranışlarını Kutsal Kitap'tan referansla destekleme yoluna gitmektedirler. Dolayısıyla Malakan inancında dinsel otorite anlayışının temelini Kutsal Kitap'ın oluşturduğunu söylemek mümkündür. Malakanlar'ın Kitab1 Mukaddes'i dini otorite olarak kabul etmeleri ile Protestanlığın Kutsal kitaba verdiği önem, her iki yapının en belirgin ortak özelliği olarak karşımıza çıkmaktadır. Onlara göre kutsal kitap insanların her an kalplerinde olmalı ve her bir Malakan fırsat bulduğunda İncil okumalıdır. ${ }^{36}$ Kutsal kitabın hem bâtıni hem de alegorik yorumunu önemseyen Malakanlar, bu sayede vaftizin, ekmek şarap ayininin ve evliliğin kutsallığını da reddederler. Ayrıca günahın onu işleyenin pişmanlığı ile ortadan kalkacağına ve hiçbir kimsenin Tanrı adına ötekinin günahını bağışlayamayacağına da inanmaktadırlar. ${ }^{37}$ Malakan inancına göre Tanrı merhametlidir ve hiçbir günah yoktur ki kişi içtenlikle tövbe ettiğinde affolunmasın. Bu nedenle günahla-

\footnotetext{
33 Morozov, Molokane, s. 3

34 Tanrı ruhtur, O'na tapınanlar da ruhta ve gerçekte tapınmalıdırlar." Yuhanna $4 / 24$.

35 Buyanov, Evgeny Valerevich, "Veroucheniye i Techeniya Dukhovnykh Khristian Molokan", Religii Rossii, Religiovedeniye, 2014/4, s. 5.

Malakhova, Dukhovnyye Khristiane, s. 90

Morozov, Molokane, s. 21.
} 
rından bağışlanmak arzusuyla transa giren bireylerin vecde geldikleri ve anlamsız ifadeler kullandıkları görülmektedir. Dolayısıyla Malakanizm inancında kişinin bir başkası karşısında günah itirafında bulunması söz konusu değildir.

Malakanizmde öne çıkan hususlardan bir diğeri de kendilerini seçilmiş bir topluluk olarak görmeleridir. Bu nedenle Tanrı'nın Krallığı tesis edildiğinde Malakanlar bu krallıkta ön safta yer alacaklardır. Malakanlar da Protestanlık'ta olduğu gibi kiliseyi miladi III. yüzyıla kadar geri götürmektedirler. Buradaki önemli fark Malakanlar'ın İznik dâhil her hangi bir konsili kabul etmiyor olmalarıdır. Oysa Protestanlar İznik Konsili ve kararlarını kabul ederler. Malakanlar'a göre Mesih'in inşa ettiği kilise, kendi varlığını ancak bu döneme kadar koruyabilmiştir. O nedenle de konsillerle birlikte şekillenemeye başlayan kilise ritüellerini, azizlerin kutsallığını ve ikonaları reddederler. ${ }^{38}$ Malakanlar'a göre düzenlenen konsiller ve Kilise babalarının ortaya koydukları görüşler zamanla hakiki Hıristiyanlığı ortadan kaldırmıştır. Bu durum yıllar geçtikçe kilise içerisinde hiyerarşinin doğmasına yol açmıştır. Oysa Tanrı, lütfu konusunda herkese eşit mesabededir.

Dualarda ve genel olarak, dini emirlerin yerine getirilmesinde, dışsal işaretlere veya yerleşik biçimlere başvurmazlar ve ibadet için özel önem taşıdığına inanılan kutsal mekân ve zamanları kabul etmezler. Hiristiyanlığın sembolü haline gelen istavroz çıkartmayı da lüzumsuz görürler ve istavroz çıkartmazlar. Toplumda hiyerarşiyi reddeden Malakanlar, İsa Mesih'in şefaati dışında, Tanrı ile insan arasında herhangi bir aracı ya da arabulucunun olmadığına inanırlar. ${ }^{39}$ Kilise Sakramentleri/gizemlerini de tümüyle reddeden Malakanlar'a göre tüm gizemler İsa Mesih'in gelişiyle açığa kavuşmuş durumdadır. Malakanlar ölülerin yeniden dirileceğine ancak bu dirilmenin bedensel açıdan değil ruhsal açıdan gerçekleşeceğine inanurlar. ${ }^{40}$ Bedenin değil de sadece ruhun yeniden dirileceği inancı, beraberinde cennet hayatının da ruhani boyutta gerçekleşeceği sonucunu doğurmuştur.

O bütün insanların kurtulup gerçeğin bilincine erişmesini ister. Çünkü tek Tanr ve Tanrı'yla insanlar arasında tek aracı vardır. O da insan olan ve kendisini herkes için fidye olarak sunmuş bulunan Mesih İsa'dır". 1. Timoteos 2/4,5,6.

40 


\section{a) Yeni Bir Mabet Fikri: Dua Evleri}

Malakan toplumunun başında seçimle belirlenen bilge ve tecrübeli biri "Presvitery/Presbytery" bulunur. ${ }^{41}$ Bu kişinin yanında ayinlerin düzenlemesinde yardım eden kıdemli okuyucu ve kıdemli anlatıcı yer almaktadır. Malakan toplumunda dini meseleler ve ritüeller bu kişilerce yönetilmektedir. ${ }^{42}$ İbadetler oldukça sade görünümlü “Dua Evi" adı verilen toplanma yerlerinde gerçekleştirilmektedir. Dua Evi, Ortodoks kiliselerin aksine çeşitli ikona ve diğer nesnelerden arındırılmış olmasıyla dikkat çekmektedir. Her konuda olduğu gibi mabet hususunda da havariler dönemini örnek alan Malakanlar, kilise benzeri özel mimarisi olan yapıları reddederler. Malakanlar'ın Şabatçı grubu dışında haftalık ibadet günleri pazardır. Dua Evlerinin bulunmadığ 1 yerlerde ise belirlenen bir evde toplanarak ibadetlerini yerine getirmektedirler. İnciller'den okunan pasajlar eşliğinde yere kadar eğilmek suretiyle ibadet ederler. Dua Evi içerisinde İncil'in okunduğu ve üzerinde beyaz örtü bulunan bir kürsü yer almaktadır. ${ }^{43}$ Dua Evinde topluluğun her bir üyesinin kendine özgü bir yeri vardır. Genelde eğitim düzeyi yüksek üyeler kürsüye daha yakın yerlerde otururken, kadınlar ayrı ve kürsüden uzak bir köşede yer alırlar. Malakanlar açısından Dua Evlerinin çok büyük önemi vardır. Zira Dua Evleri sadece Tanrı'yla birlikte olma fırsatı sunmaz aynı zamanda dindaşların bir araya gelmelerine ve sorunlarına çözüm bulmalarına imkân sağlar. Dua Evlerinde seçilmiş üye tarafından Kutsal Kitap' $\tan ^{44}$ seçilen pasajlar ve onların bâtıni yorumlarının yanı sıra ilahiler de okunmaktadır. Ayrıca ibadet esnasinda buhurdanlık ve mum kullanılmaz, birtakım nesnelere kutsallık atfederek tazimde bulunmazlar. Son aşamada ise üyeler

41 Çakır C. Suvari, Malakanlar, Rus Köylü Hareketlerinden Günümüze Malakan İnancı, Ütopya Yayınevi, Ankara 2013, s. 58.

42 Nitekim nesne ve objelere saygı göstermek, tazim amacıyla diz çökmek, kutsal addedilen nesnelere hürmet beslemek, mum yakmak ve tütsü kullanmak gibi günümüz Hıristiyanlığında yar alan uygulamalar, Roma pagan adetlerinin birer yansımasından ibarettir. Bekir Zakir Çoban, Geçmişten Günümüze Papalı, İnsan Yayınları, İstanbul, 2009, s. 54.

43 Dunn, "The Molokans in America", s. 350.

44 Malakanlar, Korintliler 3/6' da geçen "O bizi yazılı yasaya değil, Ruha dayalı yeni bir antlaşmanın hizmetkârları olmaya yeterli kıldı. Yazılı yasa öldürür, Ruh ise yaşatır" pasajına binaen Kutsal Kitabın zahiri anlamından daha ziyade batını boyutunu benimsemekteler. 
birbirlerini hafifçe eğilmek suretiyle selamlamaktadırlar. ${ }^{45}$ Böylelikle ibadet sona ermiş olur. Malakan inancında evlilik merasimi de bir sakrament olarak kabul edilmez. Evlilik törenleri dua ve ilahiler eşliğinde ebeveynlerin rızası alınmak suretiyle gerçekleştirilmektedir. Başka biri ile evlenmek amacıyla boşanmak zina ile eşdeğer görülmektedir. Sadece ölüm sonucu dul kalan eşlerin ikinci bir evlilik yapmaları uygun görülmektedir. ${ }^{46}$ Diğer inançlara saygılı olmakla birlikte Ortodokslar dâhil öteki ile evlilik de Malakanlarca hoş karşlanmamaktadır.

Malakanlar sadece "Çile Haftası" ya da "Kutsal Hafta" denilen ve İsa Mesih'in insanlık için çile çektiğine inanılan günler içerisinde oruç tutarlar. Tutulan bu orucun temel amacı istek ve arzuların eğitilmesi olmalı, asla bir gösterişe dönüştürülmemelidir. Malakanlar bir hafta süren oruç döneminde yeme ve içmeden uzak durmak suretiyle daha fazla dua ve ibadete yönelmektedirler. Ayrıca Çile Haftası dişında oruç tuttukları başka bir gün yoktur. Bu nedenle Hıristiyan inancında Paskalya bayramına hazırlık zamanı olan büyük perhiz döneminde (Lent) tüketilmesi yasak olan süt ürünlerini kullanmaktan kaçınmayı reddederler. ${ }^{47}$ Ahlak ve görgü kurallarına da büyük önem veren Malakanlar, özellikle yoksul, hasta yaşlı ve kimsesizlere yardım etmeyi bir zorunluluk hali olarak görülmektedir. Yine her ibadet sonrası yoksul ve hastalara ve aynı zamanda toplumun mevcut ihtiyaçlarının giderilmesi için maddi yardımda bulunulur yani sadaka toplanılmaktadır. Böylelikle toplum içerisinde mevcut eşitsizlik az da olsa giderilmesi amaçlanmaktadır.

Bu çerçevede Malakanlar'ın temel toplumsal taahhütnamesi şu ilkeleri içermektedir:

1. Başkalarını kıskanmayacaksın.

2. Kibirlenmeyeceksin.

3. Yakınlarını üzmeyeceksin.

4. Zina etmeyeceksin.

5. Hirsızlık yapmayacaksın.

6. Zayıflara yardım edeceksin.

7. Yaşlıları dinleyeceksin.

8. Dini Kurallara riayet edeceksin. ${ }^{48}$ 


\section{b) Toplumsal Düzen ve Ortak Mülkiyet Anlayışı}

Malakanlar'ı diğer Hıristiyan topluluklardan ayıran bir diğer unsur, dini bir cemaat olarak kendilerini ilk Hıristiyan topluluğuna benzetiyor olmalarıdır. Kendilerini ilk Hıristiyanların takipçileri ve gerçek Hiristiyanlar olarak gördüklerinden, yaptıkları tüm dinsel eylemlerde İsa Mesih'i taklit etme çabasındadırlar. Bu sebeple İsa'nın son akşam yemeğini bir sakrament olarak kabul etmeseler de onun bu davranışına istinaden sıkça toplu yemek merasimleri düzenlerler. İlk dönemlerde Malakan toplumunun Elçilerin İşleri 2:4445'te yer alan: "İmanlıların tümü bir arada bulunuyor, her şeyi ortaklaşa kullanıyorlardı. Mallarını mülklerini satıyor ve bunun parasinı herkese ihtiyacına göre dağıtıyorlardı..." ifadesine binaen toplum yapılarını buna göre şekillendirmeye çalışmışlardır. Hatta günümüz itibariyle bulundukları bölgelerde kısmen dahi olsa ortak üretim ve tüketim ilkesine uygun bir toplum yapısı oluşturmaya çalışmaktadırlar. Kilise kurumunu reddetmeleri de yine ilk dönem H1ristiyanlara benzeme çabasının bir sonucu olarak karşımıza çıkmaktadır. Malakan topluluğunun dini hayatı büyük oranda Yahudi izleri taşımaktadır. Malakanlar'a göre bu etkinin kaynağı ilk dönem Hıristiyan inancında aranmalıdır. Onlara göre günümüz itibarıyla uymaya çalıştıkları ilkeler, zamanında İsa Mesih'in sergilediği davranışlardan başka bir şey değildir. ${ }^{49}$ Malakanlar Tanrı yasasından daha üstün bir yasa olmadığı düşüncesiyle toplumsal düzenin sağlanmasında uygulanan medeni hukukun gereksizliğine inanmaktadırlar. Bu sebeple kendi aralarında Kutsal Kitap ilkeleri çerçevesinde bir yaşam tarzını ön plana çıkartma çabası içerisindedirler. Malakanlar' da iyi amel, kurtuluşun anahtarı kabul edildiğinden her işte dürüst ve doğru olmaya çaba göstermek bir ibadet olarak telakki edilmektedir. Malakanlar arasında kullanılan şu deyiş onların iş ahlakını ortaya koymak açısından önemli bir örneklik teşkil etmektedir: "ebedi yaşayacakmışsın gibi çalış, yarın ölecekmişsin gibi hayır işle" . ${ }^{50}$ Malakanlar, genellikle bu kurala uyduklarından bulundukları toplumlar içerisinde dürüst ve güvenilir kişiler olarak bilinmektedirler.

Malakan geleneğinde toplumda vuku bulan sorunlar, seçimle belirlenen Presvitery öncülügünde istişare yoluyla çözüme kavuşturulmaktadır. Malakanlar ile ilgili öne çıkan bir diğer önemli gelenek de cemaat içerisinde herhangi bir ferdin hastalığıyla ilgili

49 İvanovna, “Obshchiny Molokan na Kavkaze”, s. 133

50 Malakhova, Dukhovnyye Khristiane, s. 99 
düzenlenen genel dua merasimleridir. Hasta yakınlarının talebi üzerine bir meydana dairevi bir şekilde toplanan Malakanlar, diz çökerek ve zaman zaman secdeye kapanarak Tanrı'dan hasta için şifa niyaz etmekteler. Bu şekilde hastanın şifa bulacağına inanmaktadirlar. ${ }^{51} \mathrm{Bu}$ uygulama ile Malakanlar hasta ve ailesine manevi bir destek verirken, aynı zamanda toplum içerisinde dayanışma kültürünün de canlı kalmasını sağlamaktadırlar.

\section{c) Yeme İçme Kültürü}

Her dinin inancın kendine özgü inanç ibadet ve ahlaki özelliklerinin yanı sıra yeme içme hususuna ortaya koydukları davranış biçimleri söz konusu olmaktadır. Malakan inancında da gıda konusu oldukça önemli bir yer tutmaktadır. Her hususta olduğu gibi yeme içme konusunda da Havarileri rehber edinen Malakanlar, Havariler tarafından yasaklananlar haricindeki yiyeceklerin tümünü kutsanmış ve işaretlenmemiş olarak kabul etmektedirler. Malakan toplumunda eve davet edilen misafirler, Rabbin görkemi ve vücudun güçlendirilmesi adına diyerek sofraya davet edilmektedir. Nitekim bu Malakan toplumunda bir gelenek halini almış vaziyettedir. Sofraya oturan aile fertleri istisnasız dua etmektedirler. Yukarıda da kısmen değinildiği üzere Malakanizm inancında Yahudi inancının izlerine rastlamak mümkün olmaktadır. Bunlarda biri de Malakanlar'ın domuz etini haram kabul etmeleridir. Onlara göre İsa Mesih bir Yahudi olarak domuz eti yememiştir. Yine Cuma, Cumartesi ve Pazar günleri soğan ve sarımsak yemek yasaklanmıştır. Bunun sebebi ise Pazar günü ayin sırasında nahoş bir kokunun oluşmasının önüne geçmektir. ${ }^{52}$

Malakan inancında dini geleneğe bağlı düzenlenen toplu yemeklerde pişirilen yiyeceklerin ayrı bir kutsallığı söz konusudur. Zira bu amaçla pişirilen yemeklerin hayvanlara verilmesi yasaktır. Yine temiz sayılmayan kimseler ki bunlar lohusa veya adet halindeki bir kadın, ölüye temas eden bir kişi veya Malakan inancından olmayan bir birey örnek verilebilir, bunların bu yemeğe el sürmesi yasaktır. Yine bu yemekler özel hazırlanmış ocaklarda pişirilmektedir. Ayrıca bu günde ikram edilecek ekmekler de evlerde pişirilmektedir. Etin de Malakan yemek geleneğinde önemli bir yeri vardır. Genellikle sığır, koyun ve kuş türü hayvanların etleri tercih edilmektedir. Malakanlar'ın en fazla tükettikleri gidalar arasında

\footnotetext{
51 Morozov, Molokane, s. 56.

52 İvanovna, “Obshchiny Molokan na Kavkaze”, s. 128.
} 
kuşkusuz süt ve süt ürünleri gelmektedir. Ayrıca sebze ve meyve çeşitleri de Malakan yiyecekleri arasında önemli bir yer işgal etmektedir. Malakan inancına göre vücuda zarar veren maddelerden uzak durulması gerekir. Bu nedenle sigara ve alkollü içeceklerin kullanılması hoş karşılanmaz. Uyuşturucu veya alkol bağımlısı kişiler genellikle toplumdan tecrit edilir. ${ }^{53}$ Bunun nedeni uyuşturucu veya alkol müptelası kişinin toplumun huzurunu bozması ve istenmeyen nahoş olaylara sebebiyet vermesidir.

\section{Sonuç}

Malakanizm, Ortodoks kilisesi içerisinde oluşan hiyerarşik yapı ve ruhban sınıfının kullandığı dini tasarruflara karşı bir protesto niteliği taşımaktadır. Malakanizm'in ortaya çıkışı, büyük oranda Batı'da Protestanlığın ortaya çıkışına benzer bir görünüm sergilemektedir. Zira Protestanlık'ta olduğu üzere Malakanizm de bozulduğuna inandığı Hıristiyanlığı yeniden orijinal haline dönüştürmeyi amaçlamıştır. Malakanizm'in tarihi incelendiğinde, bu hareketin birden fazla nedenden dolayı ortaya çıktığı görülmektedir. Bunlardan ilki Protestanlıkta olduğu gibi ana bünyenin din anlayışına karşı bir protesto özelliği taşıyor olmasıdır. Nitekim Ortodoksluğun öteden beri Çarlık rejiminin resmi ideolojisini yansıtıyor olması ve politikalarını bu doğrultuda şekillendirmesi, Rus köylüsünün sömürülmesine zemin oluşturmaktaydı. Ayrıca kilise hiyerarşisi ve abartılı törenler, yoksul halk açısından pek de kabul edilir değildi. İşte bu ve benzer sebeplerden dolayı ortaya çıkan ve kilise sultasına meydan okuyan görüşler, toplum içerisinde kendisine yer edinebilmiştir. Bu çerçevede ortaya çıkan Malakanizm hareketi, toplumda mevcut eşitsizlik ve adaletsizliğe karşı Kutsal Kitap merkezli bir başkaldırı hareketi olarak da değerlendirilebilir.

Ortodoks Kilisesi içerisinden Malakanizm ve benzer dini oluşumların ortaya çıkmasının bir diğer nedeni kuşkusuz Batı'da ortaya çıkan ve zamanla Rusya'yı da etkisi altına alan Protestanlık hareketi olmuştur. Protestanlığın ortaya koyduğu din anlayışı, Malakanizm inancında kendine önemli bir yer edinmiştir. Başta kilise ritüelleri olmak üzere sakramentler, ikonalar ve top yekûn geleneğin reddedilmesi gibi radikal değişimler, Malakanizm' in karakteristik özelliğini oluşturmaktadır. Her ne kadar Malakanizm bir protesto hareketi olarak ortaya çıkmışsa da Protestanlık'tan birçok noktada ayrılmaktadır. Bunların başında sakramentler ve kurtuluş

53 Semenov, "İstoriya Zakavkazskikh Molokan i Dukhoborov", s. 56 
doktrini gelmektedir. Nitekim Protestanlık yedi sakramentten ikisini, komünyon ve vaftizi kabul ederken, Malakanizm, her hangi bir sakramenti kabul etmeyişi ile dikkat çekmektedir. Ayrıca Malakanlar kişinin kurtuluşunu onun amellerine bağlarken, Protestanlık'ta kurtuluş Tanrı'nın inayetine bağlıdır. Dolayısıyla kişinin amelleri onun kurtuluşunu sağlamakta etkin rol oynamamaktadır.

Malakanizm ve benzeri yeni dini oluşumların ortaya çıkmasını tetikleyen bir diğer unsur, kökleri on beşinci yüzyıla kadar dayanan Jidovstva benzeri heretik hareketlerdir. Yahudi inancının belirgin özelliklerini bünyesinde barındıran Jidovstva hareketi ve vazettiği inanç ilkeleri, ortaya çıkan yeni dini oluşumları önemli ölçüde etkilemiştir. Bu da Malakan inancında yer yer karşımıza çıan, domuz eti yememek, puta tapmamak ve kendilerini seçkin toplum olarak görme gibi Yahudiliği anımsatan inanışların hayatiyet bulmasına yol açmıştır.

Malakanizm her ne kadar Ortodoksluğa bir protesto mahiyetinde teşekkül etmişse de Batı' da olduğu üzere geniş bir kitleye ulaşmayı başaramamıştır. Bunun birinci nedeni Malakanizm hareketinin kendisine bir siyasi dayanak noktası bulamamış olmasıdır. Oysa Protestanlık neşet ettiğinde Martin Luther'in görüşleri bazı prenslerce desteklenmiş hatta Luther Papalığa karşı koruma altına alınmıştır. Ancak Malakanizm'in kurucusu Uklein için böyle bir durumdan bahsetmek mümkün değildir. İkinci nedene gelince, Protestanlığın kurucusu Luther, hem felsefe hem de teoloji profesörü unvanına sahip, alanında uzman bir kişilik idi. Ancak Malakanizmin kurucusu Uklein, sıradan bir Hıristiyan köylüsü idi. Dolay1sıyla siyasi bir dayanağı ve sağlan teolojik argümanları olmayan Malakanizm hareketi, sistematik bir biçimde baskı ve takibe maruz bırakılmıştır. Bu ise zamanla Malakanlar'ı tıpkı Yahudilerin yaptığ 1 gibi kendilerini Tanrı'nın seçtiği özel bir topluluk olarak görmelerine yol açmıştır.

Malakanizm hareketinde farklı kılan bir diğer önemli unsur, eşitlik ve adalet vurgusunun ön plana çıartılması ve ortak mülkiyet anlayıcı çerçevesinde oluşturulan toplum düzenidir. Hatırlanacağı üzere Malakanlar'ı böyle davranmaya sevk eden temel saik, Elçilerin İşleri 2:44-45'te yer alan pasajlardır. Malakanizm'in teşekkül ettiği sosyo-ekonomik ortam ile İsa Mesih'in bulunduğu ortam arasında bir benzerlik kuran Malakanlar, kurtuluşu ilk dönem H1ristiyanları gibi davranmakta görmektedirler. Yine bu nedenle eşitlik, adalet ve ortak paylaşım ilkeleri Malakan düşüncesinde ön 
Rus Ortodoksluğunu Protesto Etmenin İmkânı: Malakanlar/Manevi Hıristiyanlar plana çıkan unsurlar konumundadır. Sonuç olarak dürüstlük, yardımlaşma ve paylaşım gibi temelini İncil'e dayandırdıkları davranış biçimleri, Malakanlar'ın yaşamlarında önemli bir yer edinmektedir. Bu da Malakan toplumunun bulundukları bölgelerde dürüstlük ve güvenirlikleriyle tanınmalarına yol açmıştır.

\section{Kaynakça}

Andrey K. Doobovoy, "History of the Russian Protestant Religious Movement", Journal the, Say1 7-9, 1938.

Bulgakov Sergey Vasilyevich, Spravochnik po Yeresyam, Sektam i Raskolam, Direkt-Media, Moskova, 2014.

Buyanov, Evgeny Valerevich, "Veroucheniye i Techeniya Dukhovnykh Khristian Molokan", Religiovedeniye, Sayı 4, 2014.

Çoban Bekir Zakir, Geçmişten Günümüze Papalı, İnsan Yayınları, İstanbul, 2009.

Dualı Ş. Muhammed, Çarlık Rusya'sında Yahudiler, Divan Kitap, Ankara, 2016.

Dunn Ethel and Stephen P. Dunn, "The Molokans in Amerıca", Dialectical Anthropology, Vol. 3, No. 4 (1978), pp. 349-3603.

Hardwick W. Susan, "Religion and Migration: The Molokan Experience", Yearbook of the Association of Pacific Coast Geographers, Vol. 55 (1993), pp. 127-141.

Karskaya Oblast, Entsiklopedicheskiy Slovar Brokgauza i Efrona, Petersburg, Tom. XXVI (51) 1899.

Khramtsova Yuliya Sergeyevna, "Change Of Molokans Role In The Social Life of Tersk Region", Theory and Practice of Social Development, Sayı 10, 2013.

Korsakov V, Molokane Iz Zametok Zemskogo Vracha, Ruskiy Vestnik, Sayı 2, 1886.

Lane O. Christel, "Socio-Political Accommodation and Religious Decline: The Case of The Molokan Sect in Soviet Society", Comparative Studies in Society and History, Vol. 17, No. 2 (Apr., 1975), pp. 221-237.

Livanov F. V., Raskolniki i Ostrozhniki, Tom I, Izdaniye 4-oye. İzdatelstvo Sankt-Peterburg, 1872.

Malakhova İrina, Dukhovnyye Khristiane, İzdatelstvo Politicheskoy Literatury, Moskova, 1970.

Morozov İ. P, Molokane, OGIZ, Moskovskiy Rabochiy, Moskva, 1931. 
Şir Muhammed DUALI

Muratov İ, Krestyanskaya Voyna Pod Predvoditelstvom Y. I. Pugacheva (1773-1775), Prosveshcheniye, Moskova, 1980.

Musayev Elşan, "Azerbaycan'da Hıristiyanlık ve Çağdaş Hıristiyan Akımlar," (Basılmamış Doktora Tezi), Marmara Üniversitesi, İstanbul 2005.

Nikolskiy N.M, İstoriya Russkoy Tserkvi, Moskova, İzdatelstvo Politicheskoy Literatury, 1985.

Olgun Hakan, Luther ve Reformu Katolisizm'i Protesto, Eskiyeni Yayınları, 2. Baskı, Ankara, 2016.

Salin Yuriy, "Estafeta Garmonii: Ot Palestinskikh Yesseyev do Russkikh", Dalniy Vostok Dukhoborov Rossiyskiy literaturnyy Zhurnal, Sayı 2, 2006.

Semenov İ. Y, Istoriya Zakavkazskikh Molokan i Dukhoborov, Avtorskoye İzdaniye, Yerevan, 2001.

Suvari C. Çakır, Malakanlar, Rus Köylü Hareketlerinden Günümüze Malakan İnanc1, Ütopya Yayınevi, Ankara 2013. 